\title{
Kısa ve Kalp Biçimli Burunlu Kandiller ve Isparta Müzesi Örnekleri (Brants Tip 18, Loeschcke Tip 8, Broneer Tip 25, Ponsich Tip 4, Bailey Tip Q, Bussière D IX-X)
}

\author{
The Lamps with short and heart-shaped nose and Isparta Museum Examples \\ (Brants Type 18, Loeschcke Type 8, Broneer Type 25, Ponsich Type 4,Bailey Type Q, \\ Bussière D IX-X)
}

\author{
Murat FIRAT \\ Süleyman Demirel Üniversitesi, Arkeoloji Bölümü, muratfirat@sdu.edu.tr \\ ORCID Numaralar1 | ORCID Numbers: 0000-0002-5747-0869
}

\begin{abstract}
Öz: Isparta Müzesi daha çok Pisidia Bölgesi eserlerinin korunduğu önemli bir kent müzesidir. Zengin bir koleksiyona sahip bu müzenin eserleri arasında yer alan kandiller önemli bir grup dikkat çeker. Bugüne kadar ki çalışmalarda müzenin kandilleri sınıflandırılarak kısmen de olsa çalışılmıştır. Bu çalışmada ise burun üzerinde kabartı kalp uygulamasına sahip 10 adet örnek tanıtılmaktadır. Bu eserler 3 alt grup şeklinde değerlendirilir: dairesel formlu ve kulpsuz, dairesel formlu, kulplu ve diskusu bezemeli ve dairesel formlu, kulplu ve diskusu bezemesiz. İrdelenen bu eserler arasında farklı bezeme şemalarına rastlandı. Tipolojide genel form yapısının yanı sıra süsleme detayları da kriter olarak kabul edilmiştir. İrdelenen kandiller arasında bezemesiz örnekler bulunmaktadır. Bunun yanı sıra diskusunda içerisinden asma yaprakları ve üzüm salkımları çıkan krater kabartmalı ya da sıçrayan yunus balığı gibi şemalara sahip örneklerde vardır. Eserler satın alma ya da başka müzeden transfer şeklinde müzeye kazandırılmışlardır. Bu nedenle buluntu alanları belirsizdir. Dolayısıyla üretim yerleri üzerine fazla bir veri ortaya konamamıştır. Buna karşın literatür verileri doğrultusunda bu kandillerin genel olarak 2. yüzyıla tarihlendirildikleri anlaşılmıştır.
\end{abstract}

Anahtar Kelimeler: Kalp Burunlu Kandil, Roma Dönemi, Isparta Müzesi.

\begin{abstract}
Isparta Museum is an important city museum where the artefacts found in Pisidia Region are preserved. Among the artefacts of this museum which has a rich collection, oil lamps attract a significant group. Until now, the oil lamps of the museum were classified and partly studied. In this study, 10 samples with a heart relief on their noses are introduced. These lamps are evaluated as 3 subgroups: with circular form and without handle, circular form with handle and discus decoration and circular form with handle and without discus decoration. In addition to the general form structure, the details of decoration were accepted as a criteria to make a typology. There are undecorated examples among the lamps. In addition, there are examples of embossed schemas in the discus like the vine leaves and bunches of grapes emerging from a crater or splashed dolphins. These lamps were bought into the museum by buying or transferring from another museum. So that, there is not much data on the production sites. However, in light of the literature data, these candles were generally dated to the 2 nd century.
\end{abstract}

Keywords: Nose with heart-shaped, Lamps, Roman Period, Isparta Museum. 
Bu çalışmada Isparta Müzesi envanterinde yer alan burun üstü kalp biçimli kabartılı 10 adet kandil değerlendirilecektir ${ }^{1}$. Bununla birlikte çalışmada direkt olarak kandillerin irdelenmesine geçilmeden önce, öz biçimde de olsa burun üstü kalp formlu kandillerin araştırma geçmişi konu edinilecektir. Nitekim bu tip kandillere yönelik birçok çalışma bugüne kadar ortaya konmuş ve farklı tipolojiler altında değerlendirmeler gerçekleştirilmiştir. Bu bağlamda belirtmek gerekir ki, kısa biçimde de olsa, farklı tipolojilerin irdelenmesi hususu bahsi geçen eserlerin daha iyi anlaşılabilmesi ve doğru biçimde gruplanabilmeleri açısından yararlı olacaktır.

Hemen burun üstünde plastik olarak işlenmiş kalp motifine sahip olmaları ile ayrılan bu kandillere yönelik en erken çalışmalar Brants ve Walters tarafından gerçekleştirilir. Brants, Rijk Museum eserlerini irdeler. Konumuzu oluşturan tipteki kandilleri diğer kısa-yuvarlak burunlu kandillerle birlikte tip 18 altında irdeler (Brants, 1913, 53-59). Walters ise British Museum envanterinde yer alan bir grup eseri kalp biçimli burunlu kandiller başlığı altında değerlendirir. Ayrı bir grup olarak ilk defa değerlendirilen bu kandillerin kaliteli örneklerinin irdelendiği bu çalışmada eserler 3. yüzyıla tarihlendirilir (Walters 1914, s. 167-181, no. 1110-1203, fig. 234-255, pl. 30, 32, 43). Waldhauer tarafından hazırlanan bir başka katalogda faklı coğrafyalardan ele geçmiş olan ve müze envanterinde yer alan benzer örnekler kalp biçimli burunlu kandiller olarak değerlendirilir (Waldhauer, 1914, s. 14)2. Eserler, 1. - 2. yüzyıla tarihlendirilir. Loeschcke ise Vindonissa'dan tek bir örnek tanıtır. Basit yuvarlak burunlu kandiller (tip 8) grubu içerisinde değerlendirilen bu eser, 1. yüzyılın ikinci yarısı ve 2. yüzyılın ilk yarıs1 aralığına tarihlendirilir (Loeschcke, 1919, s. 227-228, no. 662, taf. III, XIII). Korinth bulgularını değerlendiren Broneer dört farklı örneği tanımlar. Eserler Tip $X X V$ grubu içerisinde irdelenir ve 1. yüzy1la tarihlenir (Broneer, 1930, s. 3, 59-60, no. 2459, pl. 10, 28). Iványi Pannonia bulgularını değerlendirir. Araştırmacı, Tip 7 altında irdelediği eserleri 1. yüzyıl ürünleri olarak yorumlar (Iványi, 1935, s. 12-13, 86-89, no. 723-724, 726, 729-730, 732-733, 745, 754, 757, taf. XVI-XXVIII).

Lerat, Université Besançon (Franche-Comté) Arkeoloji Koleksiyonu'nda yer alan kandilleri değerlendirir. Çalışma kapsamında irdelenen kandiller arasında konu edindiğimiz eserlerin benzerleri, yuvarlak burunlu kandiller gurubu altında Tip D kalp biçimli burunlu olarak ayrılır ve tanıtılır (Lerat 1954, 15-18, no. 82-97, pl. 11-12). Perlzweig'in hazırladı̆̆ 1 , Atina Agorası Roma Dönemi kandillerinin değerlendirildiği bir çalışmada ise ilginç örnekler tanıtılır. Bu çalışmada farkl formlarda kısa burunlar başlı̆̆ı altında irdelenenler 2. - 3. yüzyıla, Red on White grubu içerisine alınanlar ise 2. yüzyılın ilk yarısına tarihlendirilir (Perlzweig, 1961, s. 84-87, no. 141-143, 160-167, pl. 6). Maurétanie Tingitane kandillerinin irdelendiği bir çalışmada ise kandillerin çeşitliliğine bağlı olarak tipolojilerinin oluşturulmasındaki zorluklardan bahsedilir. Ponsich bu çalışmasında, önceki tipolojiler değinir ve ayrıca kendi tipolojik yaklaşımını da sunar (Ponsich, 1961, s. 3-26, 29-46). Araştırmacının konumuzu teşkil eden örnekte eserleri Tip IIIC altında değerlendirdiği görülür (Ponsich, 1961, s. 30, 34-35, 104-106, no. 323-345, fig. 30, pl. XXIV-XXV). Kartaca buluntularının irdelendiği çalışmada, çok sayıda kısa ve üstü kalp biçimli burunlu kandile yer verilir. Tip 8A-B Ittalya atölyeleri ve Afrika ya da dlş atölyeler şeklinde gruplara ayr1lırlar (Deneauve, 1969, s. 193-206, no. 908-1011, pl. LXXXIII-XCII). Kibris Salamis kandilleri Oziol ve Pouilloux tarafından incelenir. Araştırmacılar kalıp yapımı ana başlığı altında tip 13 ve 14 olarak bu tarz kandilleri gruplamışlardır (Oziol - Pouilloux, 1969, s. 20-21, 69, 72-76, 79-80, 82, 87-89, no. 191, 195, 204-206, 222, 230, 247, 270, 322, pl. VI-VII). Alt grupların oluşumunda kandillerin astarlı-astarsız olmaları, gövde yapıları ve bezeme şemaları gibi hususlar da kriter olarak kullanılmıştır. Szentléleky tarafından irdelenen bir grup eser ise volütsüz, dairesel burunlu kandiller başlığ 1 altında değerlendirilmiştir (Szentléleky, 1969, s. 96-97, 100, no. 145-151, fig. 145a/b-151a/b, 163a/b-166a/b). Isthmia bulgularının tanıtıldığ bir çalışmada ise Tip $X X V$ grubu içerisinde tek bir örneğe yer verilmiştir (Broneer, 1977, s. 3, 59-60, no. 2459, pl. 10, 28). İthal ürün olduğu düşünülen eser 2. yüzyıla tarihlendirilir. Kıbrıs buluntuları Oziol tarafından irdelenir. Çalışmada yer verilen kalp biçimli burunlu kandiller, klsa ve yuvarlak burunlu kandiller başlığ 1 altında fitil deliği kalp biçimli grubu içerisinde değerlendirilir (Oziol, 1977, s. 189-191, no. 556-563, 574, 584, pl. 31-33). Misır Karanis kazıları buluntusu olan bir grup Shier tarafından yayımlanır. Bu çalışmada yer verilen eserler, Broneer'in

\footnotetext{
${ }^{1}$ Bu yayında yer verilen kandiller, 1059B191800054 başvuru numaralı TÜBíTAK 2219 Yurtdışı Doktora Sonrası Araştırma Bursu kapsamında sağlanan imkânlar dâhilinde çalışılmışıtır.

${ }^{2}$ Aynı çalışmada yer alan İtalya örnekleri için bkz., s. 47-48, no. 294-299, taf. XXXI. Güney Rusya örnekleri için bkz., s. 51-54, no. 341-384, taf. XXVI- XXVIII.
} 
sınıflandırması dikkate alınarak irdelenir ve volütsüz kısa burunlu kandiller ana başlı̆̆1 altında kalp biçimli burunlu dairesel kandiller grubunda değerlendirilirler (Shier, 1978, s. 36-38, 124-127, no. 348359, pl. 6, 38-39). Karanis örnekleri 2.-3. yüzyıllara tarihlendirilir.

Bailey tarafindan hazırlanan $B M C$ II'de tip Q altında, 10 farklı alt tipte daha sistematik bir biçimde irdelenen bu grup ürünleri merkez İtalya ve özellikle Roma ve yakın çevresinde üretilen eserlerden oluştuğu belirtilir (Bailey, 1980, s. 336-376, no. 1327-1422, pl. 72-86). Tanıtılan kandillerin geneli için üretim ve kullanım süreci olarak 2. yüzyıl - 3. yüzyıl tarihleri önerilir. Royal Ontario Museum kandillerinin değerlendirildiği bir çalışmada ise Kuzey Afrika kandilleri yuvarlak burunlu tipler içerisinde iki örneğe yer verilir. Hayes tarafindan değerlendirilen bu eserler benzer örneklerden hareketle 2. - 3. yüzyıl aralığına tarihlenir (Hayes, 1980, s. 65, no. 276-277, pl. 32-33). Treviso Kent Müzesi örnekleri Zaccaria Ruggiu tarafından çalışmış ve yayımlamıştır (Zaccaria Ruggiu, 1980, s. 8284, no. 158-169). Eserlerin büyük kısmı İtalya orijinlidir. Sidi Kherabish kazıları buluntularının değerlendirildiği bir yayında çok sayıda örnekle karşılaşılmıştır. Bailey'in hazırlamış olduğu yayında gözlenen kısa kalp burunlu kandiller Loeschcke Tip VIII grubu örnekleri olarak tanıtılır. Yerel üretim olarak ayrılan bu kandillerin ağırlıklı kısmı erken 3. yüzyıl olmasına karşın, genel olarak 1. yüzyılın ikinci yarıs1 - 3. yüzyıl aralığına tarihlendirildiği görülür (Bailey, 1985, s. 129-140, pl. XXIV-XXVII). Helmann'ın katalog çalışmasında ise genel olarak 1. yüzyılın ikinci yarısı - 3. yüzyıl şeklinde tarihlendirilen klsa ve yuvarlak burunlu kandiller grubu içerisinde çok sayıda kalp biçimli burun yapısına sahip örnek tanit1lır (Hellmann, 1987, s. 78-84, no. 296-308, 310-312, 317-321, pl. XXXIXXLI).

Cosa buluntularının değerlendirildiği bir çalışmada, farklı bir grup altında bu tip kandillerin de değerlendirildiği görülür. Araştırmacılar Rickman Fitch ve Wynick Goldman tarafından hazırlanan bu yayında tombul kandiller ya da kısa, dairesel ve volütsüz kandiller başlı̆̆ 1 altında yer verilen örnekler, omuz üzerindeki bezemeye bağlı olarak başka alt gruplara da ayrılırlar (Rickman Fitch - Wynick Goldman, 1994, s. 149-183). Eserler, genel olarak 1. - 4. yüzyıl aralığında geniş bir zaman dilimine tarihlendirilir. Pisani Dossi koleksiyonu eserlerinin tanıtıldığı bir yayında yakın örnekler gözlenir. $\mathrm{Bu}$ çalışmada, disk formlu kandiller arasında Deneauve tipolojisine bağlı kalınarak Tip VIII B grubu içerisinde değerlendirilen eserler, 1. yüzyılın ikinci yarısı - 3. yüzyıl aralığına tarihlendirilir (Granchelli, Groppelli ve Rovida, 1997, s. 73-75, 80-84, no. 109-119, Tav. 15-17). Bir başka koleksiyon katalog çalışmasında çok sayıda kalp biçimli kısa burunlu kandil grubuna yer verilir. Bussière tarafından gerçekleştirilen bu çalışmada Deneauve gruplamasına uygun olarak ayrılan eserler D IX-XI tipleri arasında değerlendirilip genel olarak 2.-3. yüzyıllar aralı̆̆ına tarihlendirilirler (Bussière, 2000, s. 30-31, 103-113, no. 2908-3636, fig. 10, pl. 79-81). Heimerl, incelediği eserleri yuvarlak burunlu kandiller ana başlığ 1 altında irdeler. Kalp biçimli örnekleri ise iki alt başlık (Gruppe 9g-h: yuvarlak burunlu kalp biçimliler ve belirgin biçimde çıkıntılı ve kalp biçimli burunlular) altında tanıtır (Heimerl, 2001, s. 5759, 129-137, Gruppe 9g- $h$, no. 389-478, taf. 10-12). Araştırmcaı bu eserleri, genel olarak, 1. yüzyılın ortaları - 2. yüzyı1 şeklinde tarihler. Son dönemde gerçekleştirilen bazı tez çalışmalarında da bu kandiller konu edinilir. Tralleis bulgularını değerlendiren Civelek kalp burunlu kandiller başlığı altında 16 örneği tanıtır ve eserleri 1. yüzyıla tarihler (Civelek, 2001, s. 22-27, 76-80, no. 35-50, lev. VII-X). Kyzikos kandillerinin irdelendiği bir başka tez çalışmasında ise klsa kalp burunlu kandiller başlığı altında 15 adet eser incelenir ve ürünler 2 yüzyılın başlarına tarihlenir (Öztürk, 2003, s. 67-69, 149-163, no. 7589, lev 26-29). Bir diğer önemli tez çalışmasında ise Kibyra kandilleri değerlendirilir. Bu çalışmada tip 15, kısa kalp burunlu kandiller şeklinde ayrılan eserler genel olarak 2. yüzyıla tarihlendirilir (Metin, 2012, s. 129, 326-356, K113-165).

J. Paul Getty Museum kandillerinin tanıtıldığı bir çalışmada ise Bussière form $D I X$ ve $X$ başlıkları altında on iki alt grup içerisinde irdelenirler (Bussiere - Lindros, 2017, s. 253-305, no. 357434). Bu eserler genel olarak 1. yüzyılın ikinci yarısı - 2. yüzyıl şeklinde tarihlendirilir. Giresun Müzesi örneklerinin değerlendirildiği bir çalışmada yer verilen bir eser yine kalp burunlu kandil olarak tanıtılır (Temür, 2019, s. 315-316, no. 10). Çalışmada bu tip kandillerin 1. - 3. yüzyıl aralığına tarihlendiği belirtilir. 


\section{Eserlerin Tanıtımı}

Isparta Müzesi'nde yer alan kısa burunlu, kalp biçimli kabartılı kandiller kendi içlerinde üç farklı grupta değerlendirilebilir. Buna göre ayrılan ilk grup olan dairesel formlu ve kulpsuz kandillerden üç adet bulunur. Bu grubun örneklerinden ilki, gövde üzerinde küçük, kırık ve eksik parçalar olmasına karşın tek parça halinde korunmuştur (Levha 1, No. 1). Fitil deliğinde yoğun biçimde is izi yer alır. Eser, kalıp yapımı, dairesel formlu ve alta doğru basık haznelidir. Geniş ve az eğimli bir omuza sahiptir. Diskus derin ve dairesel formlu olup, ortasında küçük bir yağ deliği ve buruna yakın bir noktada da küçük bir hava deliğine sahiptir. Diskus deliği iç içe 3 kabartı daire ile sınırlıdır. Diskus, merkezdeki delikten dışa doğru açılan yatay, kısa ve sık çizgilerle bezelidir. Omuz üzerinde bezeme yoktur. Sadece diskusu çevreleyen içi içe kabartı daireler görülür. Burun gövdeye bitişik, kısa, düzdür ve oval formlu bir fitil deliğine sahiptir. Dip, hafif içbükey formlu olup halka biçimli bir yivle sınırlıdır. Yaklaşık merkezinde olasılıkla atölyeyi işaret eden " $\triangle$ HMOC@ENOYC (Demosthenes'e ait)" yazısı iki sıra halinde, alt alta ve kabartı olarak işlidir. Grubun ikinci örneği nerdeyse her açıdan ilk örnekle uyumludur $^{3}$ (Levha 1, No. 2). Sağlam durumda ele geçmiştir. Aynı şekilde fitil deliğinde is izi gözlenir. Kalıp yapımı, gövdesi dairesel formlu, geniş derin haznelidir. İçbükey diskus iç içe çemberlerle sınırlanır. Diskusun merkezinde yer alan yağ deliği çevresinde ışınlar ve ayrıca diskus-burun tarafinda havalandırma deliği yer alır. Az miktarda eğimli ve bezemesiz bir omuzdan dibe doğru daralan gövde halka formlu diple sonlanır. Bu örneğin tabanında olasılıkla atölyeyi işaret eden, belli belirsiz halde korunmuş ve alt alta iki sıra halinde kazıma olarak işlenmiş olan "ГLYK.. -NOC" harfleri seçilir. Grubun son örneği olan 3 numaralı kandil de tek parça halinde korunmuștur (Levha 1, No. 3). Buna karşın gövdesinin genelinde küçük, kırık ve eksik parçalar gözlenir. Fitil deliğinde yoğun biçimde is izi bulunan eser kalıp yapımı, dairesel formlu ve alta doğru basık haznelidir. Geniş ve az eğimli bir omuza sahiptir. Diskus derin ve dairesel formlu olup, merkezinde küçük bir yağ deliğine sahiptir. İç içe dairelerle sınırlandırılmıştır. Omuz üzerinde yumurta dizisi yer alır. Eserin fitil deliği ovaldir. Dip ise hafif içbükey formlu olup, halka biçimlidir.

Çalışmamızda yer verilen eserlerden ikisi bir başka alt grup altında toplanır. Dairesel gövdeli, kulplu ve diskusu bezemesiz olan bu kandillerden ilki tek parça halinde korunmuştur (Levha 2, No. 4). Gövde de küçük, kırık ve çatlaklar gözlenir. Fitil deliğinde is izi yer alır. Eser kalıp yapımı ve alta doğru basık haznelidir. Geniş ve az eğimli bir omuza sahiptir. Omuz üzerinden itibaren yükselen yüzük formlu kulp gövde altına kadar uzanır. Diskus içbükey ve çevresinde dairesel yivli olup, tam ortasında küçük bir yağ deliğine sahiptir. Kandilde herhangi bir bezeme şeması uygulanmamış, sade bırakılmıştır. Kaide, hafif içbükey formlu olup dairesel bir yiv ile çevrelenir. Bu grubun ikinci örneği tek parça halinde korunmuş olup, gövde ve kulp üzerinde küçük, kırık ve eksik parçalar gözlenir (Levha 2, No. 5). Fitil deliğinde is izi yer alır. Eser kalıp yapımı, dairesel formlu ve alta doğru basık haznelidir. Geniş ve az eğimli bir omuza sahiptir. Omuz üzerinden yükselen yüzük formlu kulp gövde altına kadar uzanır. Diskus derin ve çevresinde dairesel yivli olup, ortasında küçük bir yağ deliğine sahiptir. Omuz üzerinde bezeme bulunmaz. Kaide, hafif içbükey formlu olup dairesel bir yiv ile çevrelenir. Genel özellikleri ile değindiğimiz bu kandil arasındaki en belirgin fark omuz yapılarıdır. Dikkatli gözlemlendiğinde, ilk eserin omzunun ikinci örneğe oranla daha dar ve dik bir profil sunduğu görülür. Her iki eserde ortak olan bir diğer özellik ise beyaz astar kullanımıdır. Bu yönleriyle red on white grubu içerisinde düşünülebilirler.

Üçüncü ve son alt grup ise dairesel gövdeli, kulplu ve diskusu bezemeli kandillerden oluşur. $\mathrm{Bu}$ eserlerden ilki tek parça halinde korunmuş olmasına karşın, omuz ve diskusun bir kısmı, kırık ve eksiktir (Levha 3, No. 6). Fitil deliğinde is izi yer alır. Red on White grubu özellikleri sunan bu eser kalıp yapımıdır. Geniş ve az eğimli bir omuza sahiptir. Arkada omuz üzerinden itibaren yükselen yüzük formlu kulp gövde altına kadar uzanır. İçbükey diskus derindir. Çevresi dairesel kabartı yivle sınırlanmış olup, ortasında küçük bir yağ deliğine sahiptir. Diskusta sola doğru koşar halde erkek geyik figürü yer alır. Figürün arka ayakları yere basmakta olup, ön ayakları ise harekete bağlı olarak hafif kendine çekilmiş ve ileri doğru atılmıştır. Sırt-sağrı hattı düzdür. Boyun dik ve baş tam karşıya bakacak biçimde konumlandırılmıştır. Kuyruğu da yukarı doğru ve hilal biçiminde tasvir edilmiştir. Boynuz ana hattan

\footnotetext{
${ }^{3}$ Bu kandil daha önceden bir başka çalışma kapsamında ele alınmış ve yayımlanmıştır. Bkz. Fırat - Metin, 2011,
} s. 146 , no. 4 , res. 4 , çiz. 4 . 
ayrılan 3 farklı kol șeklinde izlenir. Dikkatli bakıldığında sol ve sağ kulak görülebilir. Figür genel olarak silikleşmişse de, toynaklar gibi bazı detaylar algılanabilmektedir. Kandilin omuz üzerinde ise bezeme olarak yumurta dizisi işlidir. Kaidesiz olan eserin tabanı hafif içbükey olup dairesel bir yiv ile sınırlanır. $\mathrm{Bu}$ alt grubun ikinci örneği tek parça halinde korunmuştur. Formun genelinde küçük, kırık ve eksik parçalar gözlenir (Levha 3, No. 7). Fitil deliğinde is izi kalmıştır. Kalıp yapımı, dairesel formlu ve alta doğru basık haznelidir. Geniş ve az eğimli bir omuza sahiptir. Diskus derin ve dairesel formludur. İç içe kabartı dairelerle sınırlandırılmıştır. Diskus açıklığ 1 ise küçük olup, merkezde işlenmiş olan kraterin hemen solunda ve diskus-omuz birleşim hattında yer alır. Kandilin omuz kısmı geniş ve az eğimlidir. Üzerinde yumurta dizisi işlenmiştir. Burun gövdeye bitişik, hafif bir çıkıntı biçiminde ve üstü kalp formludur. Fitil deliği ovaldir. Dip, hafif içbükey formlu olup dişta halka biçiminde derin bir yivle sınırlanmıştır. Tondada belli belirsiz bir planta pedis görülür. Eserin diskusunda ve tüm alanı kaplayacak şekilde, merkezde yer alan yüksek bir kraterden çıkan asma yaprakları ve üzüm salkımları izlenir. İnceuzun biçimde tasvir edilen bu krater tam merkezde yer alır. Krater geniş bir ağza, ince-uzun boyun ve projeksiyon noktası omuz üzerinde kalan daha geniş bir gövdeye sahiptir. Ayakları da yine inceuzundur. Taban kısmı seçilemese de ayak kısmının tamamen boğumlar biçiminde tasvir edildiği görür. Kraterin ağzının hemen üzerinden yükselen karşılıklı iki kulp "S" profil yaparak gövde omuz hizasında kap ile tekrar birleşir. İşlenen şemayı daha da zengin kılan asma dalları, iki ana kol halinde kraterden çıkar ve yükselirler. Kulpları geçtikten sonra ise aşağı doğru salınırlar. Yaklaşık simetrik biçimde işlenen iki büyük yaprak ve altta kalan küçük yapraklarla donatılıdırlar. Kraterin her iki yanında simetrik olarak yerleştirilen iki üzüm salkımı bezeme şemasına ayrı bir zenginlik katar. Bu görünüm ara dallarla da desteklenir. 8 ve 9 numaralı kandiller bu alt grubun son örnekleridirler. Her ikisi de tek parça halinde korunmuşlardır. Buna karşın üzerlerinde küçük, kırık ve eksik parçalar gözlenir (Levha 3, No. 8-9). Eserlerin fitil deliğinde is izi gözlenir. Kalıp yapımı, dairesel formlu ve alta doğru basık haznelidirler. Geniş ve az eğimli bir omuza sahiptirler. Diskuslar derin ve dairesel formlu olup, iç içe kabartı dairelerle sınırlandırılmıştır. Diskus açıklıklarında farklılıklar gözlenir. 8 numaralı eserde bu delik merkeze figür yerleştirildiği için biraz kulpa yakın bir noktada, geride kalır. 9 numaralı eserde ise yine merkezde figür yer aldığ 1 için delik figürün hemen altında ve biraz solunda kalacak biçimde yerleştirilmiştir. 8 numaralı eserde yaklaşık dikdörtgen formlu ve daha küçük boyutlu ekstra bir havalandırma deliği burun hizasında ve omuza yakın bir alanda konumlandırılmıştır. Her iki eserde de diskus içerisinde merkezi olarak yerleştirilmiş aynı tipte tek bir yunus figürü izlenir. Yunus figürleri çok belli olmamakla birlikte kızgın bir yüz ifadesine sahiptirler. Ağız hafif açık ve gözler iridir. Baş kısmı hafif öne eğik olan figürlerin kuyrukları ise yukarı doğru kıvrılarak yükselir. Kandillerin omuz kısmı geniş ve az eğimlidir. Bu alanda yumurta dizisi işlenmiştir. Burunlar gövdeye bitişik, hafif bir çıkıntı biçiminde ve üstü kalp formludur. Fitil delikleri ovaldir. Dipler, hafif içbükey formlu olup dişta halka biçiminde derin bir yivle sınırlanmıştır. 8 numaralı kandilin tondosunda belli belirsiz bir planta pedis görülür. Diğer örneğin tabanı aşırı biçimde yıprandığı için planta pedis veya başka bir uygulamanın olup olmadığı hususu belirsizdir. Grubun son örneği tek parça halinde korunmuş olup, gövde ve kulp üzerinde küçük, kırık ve eksik parçalar gözlenir (Levha 3, No. 10). Fitil deliğinde is izi yer alır. Kalıp yapımı, dairesel formlu ve alta doğru basık haznelidir. Geniş, az eğimli omuza sahiptir. Omuz üzerinden itibaren yükselen kulp gövde altına kadar uzanır. Diskus derin ve çevresinde dairesel yivli olup, ortasında küçük bir yă̆ deliğine sahiptir. Diskus içerisinde tüm boş alanı kaplayacak biçimde, kulp kısmından buruna doğru açılan olasılıkla on bir bölümden oluşan bir midye kabuğu motifi yer alır. Kabuğun açılım noktası yuvarlak bir kabartı şeklinde belirginleştirilir. Bu noktada küçük bir kurdele görüntüsü oluşturulmuştur. Diskusun ortası kırık ve eksiktir. Bununla birlikte diskusta yer alan küçük bir hava deliği yaklaşık burunomuz hizasında korunmuştur. Bu kandilin omuz üzerinde bezeme bulunmaz. Burun ise kısa-kalp biçimli ve gövdeye bitişik olup, dairesel formlu fitil deliklidir. Tabanı, hafif içbükeydir ve dairesel iç içe iki yiv ile çevrelenir.

\section{Genel Değerlendirme ve Sonuç}

Bu çalışmada Isparta Müzesi’nde korunmakta olan 10 adet kısa-kalp formlu burunlu kandil konu edinilmiştir. $\mathrm{Bu}$ kandillerin tipolojilerinin oluşturulması hususu çok farklı çalışmalarda irdelenmeye çalışılmıştır. Bu yayınların bir kısmında sadece gövde yapısı esas alınırken, kimilerinde gövde yapılarının yanı sıra burun profillerini de dikkate alan gruplamaların ön plana çıktığı görülür. Birçok yayında ise bunlara ek olarak, bezeme şemaları ve kulp uygulamaları da değerlendirme öğesi 
olarak kullanılır ${ }^{4}$. Bu çalışmada ise kandillerin gruplanması için son dönemde daha çok tercih edilen burun yapısına göre tipoloji öncelikli olarak kabul edilmiştir. Buna bağlı olarak da irdelenen kısa ve kalp biçimli kabartılı burunlu kandiller dairesel formlu ve kulpsuz, dairesel formlu, kulplu ve diskusu bezemeli ve dairesel formlu, kulplu ve diskusu bezemesiz şeklinde üç alt grupta toplanmıştır.

Bu alt gruplardan ilki Isparta Müzesi örnekleri arasında 3 örnekle temsil edilir (No.1-3). Hemen hemen aynı bezeme şemasına sahip olan, 1 ve 2 numaralı kandillere çok benzeyen bir örnek Pergamon'da ele geçer. Kulplu olan ve burun kısmı korunmayan bu kandil, Gruppe 10 (perg) içerisinde değerlendirilir ve 1. yüzyllın ikinci yarısına tarihlenir (Heimerl, 2001, s. 61-62, 151, no. 650, taf. 15). U biçimli burun yapısı ve kulp eklentisi açısından ayrılan, bununla birlikte özellikle diskus bezeme şeması ve aynı şekilde buruna yakın bir noktada yer verilen havalandırma deliği ile benzer olan bir başka eser, Walters tarafından irdelenir. Dairesel gövde, geniş omuz yapısı ile son derece benzer olan bu kandil 2. yüzy1la tarihlendirilir (Walters, 1914, s. 155, no. 1038, pl. XXXII). Kulp eklentisi yönüyle ayrilan ancak diskus şeması açısından özellikle 2 numaralı kandile çok benzeyen bir örnek Kartaca kandilleri yayınında yer alır (Deneauve, 1969, s. 193, no. 910, pl. LXXXIII). Tip VIIA grubu içerisinde irdelenen kandil, benzer biçimde tarihlendirilir. Aynı şekilde özellikle diskusunda görülen 1şın bezemesi ile benzer bir başka örnek Tralleis kazılarında M.28 mezarında saptanır (Civelek, 2001, s. 79, lev. IX, K49). Söz konusu eser 1. yüzyılın ikinci yarısına tarihlenir. Knidos kazıları buluntuları tarihleme hususunda faydalıdırlar. Knidos kandillerini inceleyen Pastutmaz, benzer örnekleri 2. yüzyılın ilk yarısına tarihler (2001, s. 76, res. 105). Bunların dışında Royal Ontario Müzesi'nde yer alan kandilleri yayınlayan Hayes, bu tipin 50-100 arasında Orta İtalya seramik atölyelerinde üretilmiş olabileceğini ileri sürer (Hayes, 1980, s. 54, pl. 26, fig. 244). Elimizdeki örneklerin hem tabanlarındaki yazı hem de form ve bezeme şemasında gözlenen değişkenliklerden yola çıkarak farklı bir atölyede üretildiği düşünülebilir. Eserler benzerlerinden hareketle ise 2. yüzyılın ilk yarısına tarihlenebilir. Bu grubun son örneği olan no. 3, diskusunda bezeme bulunmaması yönüyle ayrılır. Bu kandilin en yakın benzeri Atina Agorası'nda tespit edilir. Perlzweig tarafından irdelenen eser için 2. yüzyıl tarihi önerilmektedir (Perlzweig, 1961, s. 84, no. 133, pl. 5). Kulp eklentisi hariç genel form yapısı ve omuz üstü bezemeleri açısından uyumlu iki örnek Bailey tarafından tanıtılır (Bailey, 1988, s. 370, 380, Q3085-3086, pl. 103). Ephesus ürünü olarak yorumlanan bu kandiller, 2. yüzyılın başlarına tarihlendirilir. Aynı çalışma da yer verilen ve önceki eserlerle aynı grup altında irdelenen bir başka örnek ise omuz üzerinde yumurta dizisi yerine pelta dizisi yer alması ve ayrıca kulp eklentisi ile Isparta Müzesi kandilinden ayrılır (Bailey, 1988, s. 370, 380, Q3084, pl. 103, fig. 97-98, 142-143). Bu eserlerde gözlenen en önemli fark ise diskusta yer verilen tekil hayvan figürleridir. British Museum' daki Knidos kandili olarak tanıtılan bezemesiz bir örnek için ise 2 . yüzy1l tarihi uygun görülür (Bailey, 1988, s. 349, no. Q2815, pl. 88). Goethert Polaschek Trier Müzesi örneklerini aynı sürece tarihler (Goerth Polaschek, 1985, s. 166, taf. 72, M236). Kibyra kandilleri arasında da çok yakın bir örnek gözlenir ve tanıtılır (Metin, 2012, s. 138, 346, K149). Form yapıs1 itibariyle birebir benzer olan bu örnek, kulp eklentisi ve burunda gözlenen küçük detaysal farklılıklar ile ayrılır. Eser 2. yüzyılın ilk yarısına tarihlendirilir. Akşehir Müzesi kandillerinin irdelendiği bir çalışmada ise yuvarlatılmış burun yapısı ile ayrılan ancak diğer özellikleri ile uyumlu bir örnek Tekocak tarafından yayımlanır (Tekocak, 2013, s. 712, 719-720, no. 9, fig. 9). A.Tip VI grubu içerisinde değerlendirilen bu kandil, tabanında uygulanan ve olasılıkla üreticiye işaret eden kazıma yazıtın uygulanma yeri ve uygulama biçimi ile de özellikle 1 numaralı kandile benzer. Eser, 1. yüzyıla tarihlendirilir.

Ana tip altında irdelediğimiz ikinci gruba ait iki önek ise 4 ve 5 numaralı kandillerdir. $\mathrm{Bu}$ eserlerin benzerleri de birçok farklı çalışmada tanıtılır. İrdelediğimiz eserlerin en yakın örneklerinden birisi Kyzikos'ta ele geçer. Gerek tipolojik olarak gerekse süsleme detayları açısından son derece benzer olan bu kandil, geç 2. yüzyıla tarihlendirilir (Öztük, 2003, s. 67-69, 156, no. 82, lev 28a). Kil ve renk detayları açısından uyuşmasa da tipolojik olarak en yakın örneklerden oluşan bir grup ise Pergamon'da saptanır. Pergamon ürünü olan eserler Gruppe $9 g$ (perg) altında irdelenir ve 1. yüzyılın ikinci yarısı erken 2. yüzyıl aralığına tarihlendirilir (Heimerl, 2001, s. 57-58, 135-136, no. 456-467, taf. 11). Form olarak benzerlerinin izlenebildiği bir diğer çalışma Kibyra kandilleri içeriklidir. Yerel üretim oldukları düşünülen ve sadece genel görünüm açısından konu edindiğimiz kandillerle uyumlu olan bu eserler, 2.

\footnotetext{
${ }^{4}$ Bkz., dip notlar 2-30.
} 
yüzyılın ilk yarısı ve biraz sonrası biçimde tarihlendirilirler (Metin, 2012, s. 343-356, no. 143-165). Yakın tarihlere verilen ancak burun tipi açısından ayrılan iki örnek ise Atina Agorası'nda tespit edilir (Perlzweig, 1961, s. 4-5, 83, 88, no. 126, 176, pl. 5, 7). Bunlardan özellikle ikincisi red on white grubu kandili olması açısından ayrıca benzerlik sunar. Eser erken 2. yüzyıl şeklinde tarihlendirilir. Son dönemde tamamlanan bir tez çalışmasında da, omuz üstü bezemesi dışında son derece benzer bir başka eser tanıtılır'. Tralleis'te saptanan bu örnek, 2. yüzyılın ilk yarısına tarihlendirilir.

Üçüncü ve son alt grubun ilki 6 numaralı kandildir. Rijks Müzesi eserlerinin irdelendiği bir çalışmada volütlü kandil tiplerinden birinin diskusunda yakın bir tema işlidir (Brants, 1913, s. 18, no. 232, pl. III). İleri doğru zıplar pozisyonda tasvir edilen geyiğin boynuz ve aşağı doğru inen kuyruk detayları açısından farklılıklar gözlenir. Aynı çalışmada genel form yapısı ve omuz üstü bezeme şeması ile uyumlu olan buna karşın, diskusta yer alan figürün oturur pozisyonda tasviri ile ayrılan ilginç bir başka örnek de gözlenir (Brants, 1913, s. 45, no. 801, pl. V). Vindonissa eserleri arasında tanitılan bir eser, diskus şeması açısından benzerdir. Bununla birlikte işlenen geyik figürünün özellikle ön sol ayağının pozisyonu, başını daha yukarı çevirmiş olması, kuyruğunun farklı biçimde aşağı yönlü tasvir edilmesi gibi küçük detaylar açısından farklılıklar göze çarpar (Loeschcke, 1919, s. 214, no. 501, pl. XIII, LII, LXIII, LXXXVI). Boyutları arasında küçük bir fark olsa da renk, astar, kil ve kalıp özellikleri açısından birebir uyumlu red on white grubuna dâhil bir başka kandil, Atina Agorası'nda ele geçer. Her iki eserin diskusunda geyik figürü tam olarak aynı pozisyon ve özelliklerde işlenmiştir. Diskus deliği de aynı yere konumlandırılmıştır. Omuza geçişte kullanılan kabartı halkaların genişlikler ve sayıları aynıdır. Omuz üzerinde görülen, her iki örnekte de yine aynı şekilde uygulanan dil motifi şablonu, son derece uyumludur. İki eser arasında bezeme şeması açısından gözlenen belki de tek fark burun üstüne konumlandırılan plastik kalp uygulamasının biraz farklı olmasıdır. Erken 2. yüzyıla tarihlendirilen bu eserin üretim yeri olarak ise Ephesos veya yakınlarındaki (Priene veya Smyrna gibi) bir kent önerilir (Perlzweig, 1961, s. 5-6, 86, no. 163, pl. 7). Kartaca kandillerinin irdelendiği bir çalışmada çok sayıda farklı tipte burun yapısına sahip ancak benzer temalı eser yayımlanır ${ }^{6}$. Eserler 1. - 2. yüzyıla tarihlendirilir. Szentléleky'nin hazırlamış olduğu bir başka kandil çalışmasında, iki benzer örnekle karşılaşılır. Bunlardan ilki volüt burunlu kandil olup, üzerindeki diskus şeması açısından son derece yakın bir benzerlik sunar (Szentléleky, 1969, s. 69-71, no. 82a-b). Aynı çalışmada irdelemekte olduğumuz kandilin gerek tip gerekse bezeme şeması açılarından son derece uyumlu bir başka örneği de, Yunan Adaları ürünü olarak tanıt1lır (Szentléleky, 1969, s. 97, 101-14, no. 150a-b). Bu eserin profil detayları, diskusta uygulanan figürün duruş pozisyonu, kuyruğun betimi ve hatta boynuzlarda gözlenen dalların sayısı ve yönü, omuz üstü süsleme şablonu vb. hemen her açıdan Isparta Müzesi örneği ile son derece uyumludur. Buna karşın daha küçük ölçülerde bir kandildir. Zaten diskusta yer alan geyik figürü sanki alana sığmamış gibi diskusdan taşacak biçimde durmaktadır. Gerek boyutlar gerekse renk skalası açısından Agora buluntusuna daha yakındır. Royal Ontario Museum kandilleri arasında da gerek tipolojik ve gerekse diskus bezeme şeması açısından yakın iki örnek yer alır. Kilikia grubu içerisinde değerlendirilen ve yerel üretim olarak tanıtılan bu iki eser, tipolojik olarak Isparta Müzesi örneği ile uyumludur. Sadece kulp eklentisi görülmez ve omuzları daha yuvarlak formludur. Diskus şeması açısından ise oldukça benzer olmalarına karşın detaysal olarak (boyun, kuyruk ve boynuz) farklılıklar göze çarpar (Hayes, 1980, s. 72-73, no. 297, 301, pl. 37). Özellikle omuz üstünde aynı bezeme uygulaması ile ilk eserin daha benzer olduğu gözlenir. Bu örnek geç 1. yüzyıl - 2. yüzyıl şeklinde

\footnotetext{
${ }^{5} \mathrm{Bu}$ eser tam olarak belirtilmemiş olsa da üzerindeki beyaz astar izlerinden hareketle red on white grubu örneklerinden birisi olabilir. Bkz., Aydın, 2015, s. 33-37, 82, K16, lev. XX.

${ }^{6}$ Deneauve, 1969, s. 118, 139-140, 156, 199, no. 353, 500-503, 624, 953, pl. XL. Bu çalışma da yer verilen 353 numaralı ok ucu biçimli ve volütlü burunlu kandilin diskusunda zıplayan geyik teması tam olarak ilk zıplama anının tasviri şeklindedir. Bu yüzden ön ayaklar gövdeye oldukça bitişik biçimde tasvir edilmiştir. Ayrıca bu geyiğin kuyruğu poposuna doğru kapanmıştır. Aynı çalışmada yer verilen yuvarlak formlu ve volütlü burunlu 4 farklı kandilde de diskusta zıplayan geyik figürü işlenmiştir (no. 500-503). Bu eserlerden ilk üçü tek kalıptan çekilmiş gibilerdir ve Isparta Müzesi örneğinde birçok detayda ayrılırlar. Bununla birlikte 503 numaralı örnekte gözlenen figür sadece başının biraz daha geriye ve yukarı doğru açılması nedeniyle farklılık göstermiş olur. 624 numaralı eser bir başka yuvarlak formlu ve volütlü burunlu kandildir. Bu eserde görülen geyik ise kuyruğunun yukarı doğru ama daha dik bir yükselmesi ve arka ayaklarının işlenişi gibi küçük detaylar ile farklılaştığı görülür. 953 numaralı eser ise form yapısı olarak da benzer olan bir kandildir. Bu eserin diskusunda görülen geyik figürü oldukça kaslı ve iri gövde yapısı ile ciddi biçimde farklılaşır.
} 
tarihlenir. Alba-la-Romaine buluntuları arasında yer alan bir örnek volütlü kandiller grubu tip 1A altında irdelenir (Ayala, 1990, s. 191-192, no. 15, fig. 14). Figür genel duruş pozisyonu açısından uyumlu olsa da, özellikle arka ayaklarının ve sağrısının işlenişi, kuyruk duruşu vb. küçük detaylarda farklılık gösterir. Kyzikos'ta yürütülen kazı çalışmaları neticesinde tespit edilen benzer bir şema, kısa sarmallı U burunlu kandiller grubu altında tanıtılır (Öztürk, 2003, s. 65-66, 134, no. 60. lev. 20). Genel duruş itibariyle benzese de özellikle arka ayakların havada olması ve kuyruğun geriye ve aşağı doğru tasviri yönüyle ayrilır.

Grubun ikinci örneği olan 7 numaralı kandilin diskusunda yer alan bezeme uygulamasının yakın benzerlerinin geniş bir coğrafyada ve farklı tipte kandillerde, 1. yüzyıldan itibaren sevilerek kullanıldığı anlaşılmaktadır ${ }^{7}$. Eserin kalıp açısından en yakın benzerlerinden birisi Pergamon'da ele geçmiştir. Pergamon üretim olan kalıbın uygulandığı bu eser volütlü kandildir ve 25-75 aralığına tarihlenir (Heimerl, 2001, s. 53, 112, no. 183, motiv 350, taf. 5). Aynı çalışmada yer verilen bir başka kandil ise form ve genel şema açısından Isparta Müzesi örneği ile son derece uyumlu olsa da, diskus üzerinde yer alan kraterin boyutları ve salkım dizaynı açısından biraz ayrılır. Ayrıca bu eserde iki diskus deliği uygulaması tercih edilmiştir. Gruppe $9 g$ (perg.) içerisinde değerlendirilen bu eser 2. yüzyılın ilk yarısına tarihlendirilir (Heimerl, 2001, s. 58, 133, no. 428, taf. 11). Bu genel özelliklerin yanı sira her iki eser, kil ve astar uygulamaları açısından da Isparta Müzesi örneğiyle son derece benzerdir.

Isparta Müzesi eserleri arasında olan ve değerlendirmeye alınan 8 ve 9 numaralı kandillerin yakın benzerlerine farklı çalışmalarda yer verilmiştir ${ }^{8}$. Buna karşın en yakın örnek Kibyra'dan ele geçer. Metin tarafından hazırlanan Kibyra kandilleri içerikli doktora tezi çalışmasında, diskusta yunus balığı betimi bulunan yedi eser değerlendirmeye alınmıştır' . Bu eserlerden özellikle K137 numaralı olan tip, süsleme detayları, yunus figürünün işlenişi, tabanda gözlenen planta pedis, boyutlar, kil ve astar uygulamaları gibi pek çok noktada çok yakındır. En büyük fark, yunus figürünün kendi soluna doğru dönmüş olmasıdır (Metin, 2012, s. 71-72, 338-339, K137). Eser, 2. yüzyılın ilk yarısı şeklinde tarihlendirilir. Heimerl tarafından irdelenen Pergamon buluntuları arasında da çok yakın örnekler gözlemlenir. Gruppe 9g (prg.) başlığ 1 altında irdelenen eserler gerek tipolojik gerekse omuz üstü süsleme detayları açısından uyumludurlar (Heimerl, 2001, s. 131-132, no. 413-419, motiv 219, taf. 10). Diskusta işlenen yunus figürleri tip ve hareket yönünden benzer olmalarına karşın, Isparta Müzesi

\footnotetext{
7 Kıbrıs bulguları için bkz Oziol, 1997, s. 124, no. 315, 317, Nic. D 2687, 2731, pl. 18; Gordon - Cova, 2010 , s. 284, fig. 9; Galya ve Knidos verileri için bkz., Bailey, 1988, s. 50, 151-152, 159, 327, 331, 335, 346, Q1509, Q2670, Q2786-89, P1. 2, 74, 86, Fig. 50, 129; Miletos bulguları için bkz., Heres, 1968, s. 189, 192, nr. 36, 53, abb. 12, taf. 32/5; Ephesos buluntusu için bkz., Ladstätter, 2013, taf. 222, 233, B-K 428; Myrina örneği için bkz., Heres, 1968, s. 193; Alba-la-Romaine örneği için bkz., Ayala, 1990, s. 199, no. 76, fig. 16; Rittium bulgusu için bkz., Heres, 1968, s. 193, nr. 102, taf. 33/9; Pergamon verileri için bkz., Heimerl, 2001, s. 150, 204, Gr. 10 (perg), Motiv 351 - 352, bei. 12, taf. 15; Kenchreiai örneği için bkz., Williams, 1981, s. 30, no. 140; Mainz Müzesi'nden bir örnek için bkz., Menzel, 1954, s. 38, nr. 176, abb. 31/4; British Museum örneği için bkz., Walters 1914, 109, no. 725, pl. 24; Rijks Müzesi volütlü ve u burunlu tipte kandillerde uygulanan örnekler için bkz., Brants, 1913, s. 18, 21, 49, no. 273, 909, pl. III, VI; Berlin Eyalet Müzesi'nde bulunan bir Aleksandreia buluntusu için bkz., Heres, 1967, s. 117, taf. 34/2; Aleksandreia Troas antik kentinde ele geçen $u$ burunlu bir kandilde görülen benzer şema için bkz., Fırat, 2014a, s. 218, 224, no. 17, lev. 18.

${ }^{8}$ Vindonissa kandillerinde yunus betimleri için bkz., Loeschcke, 1919, s. 195, 216-217, no. 296-297, 533-536, 601, taf. III, XIV; Atina Agoras1 örnekleri için bkz., Perlzweig, 1961, s. 129, no. 930-942, pl. 20; Maurétania Tingitane örneği için bkz., Ponsich, 1961, s. 90, no. 138, pl. XIII; Ontario Müzesi örnekleri için bkz., Hayes, 1980 , s. 50, 99-100, no. 226, 394, pl. 22, 47, 49; Kıbrıs Salamis bulguları için bkz., Oziol, 1977, s. 166-167, no. 505, pl. 26; Mampsis örneği için bkz., Rosenthal Heginbottom, 1981, s. 66-67, abb II.2, taf. 6; Macaristan Güzel Sanatlar Müze'sinden bir örnek için bkz. Szentléleky, 1969, s. 68, no. 79a-b; Ephesos örneği için bkz., Bailey, 1988, s. 73, 366-369, 375, no. Q3030, fig. 92, pl. 99; Metropolis kenti bulguları için bkz., Güngör, 2011, s. 264-266, no. 169171.

${ }^{9}$ Benzer tasvirlerin olduğu örnekler için bkz. Metin, 2012, s. 71-72, 337-339, 420-421, K134-K137, K286-287, KS23. Bu çalışmada yer alan özellikle, K134-K136 numaralı örnekler için sola doğru yerleştirilen yunus balıkları, Poseidon'un atribütü üç dişli yaba ile birlikte betimlenmiştir. Yunus balı̆̆ Yunan mitolojisinde Poseidon'u simgeler. Dolayısıyla buradaki bezemenin Poseidon'un hoşnutluğunu kazanmaya yönelik olma ihtimali yüksektir. şeklinde bir yoruma da yer verilmiştir. Bkz., Metin, 2012, s. 71-72.
} 
örneğinden farklı olarak, kuyrukları birbirine dolanmış çift yunus şeklinde betimlenmişlerdir. $\mathrm{Bu}$ kandiller 2. yüzyılın ilk yarısına tarihlendirilir.

Grubun son örneği olan 10 numaralı kandilin benzerlerinin farklı çalışmalarda tanıtıldığı görülür ${ }^{10}$. Tip ve bezeme şeması açısından en yakın eserlerden birisi Atina Agorası'nda bulunmuş ve 2 . yüzyılın ikinci yarısı - 3. yüzyılın başları aralığına tarihlendirilmiştir (Perlzweig, 1961, s. 85, no. 143, pl. 6). İthal grup içerisinde değerlendirilen bu örnek, diğer özelliklerinin yanı sıra astar rengi açısından da benzerdir. Hatta ilginç biçimde diskustaki deliğin etrafında oluşan kırık ve eksik parça açısından da neredeyse uyumludurlar. Her iki eser arasındaki en önemli fark, Agora buluntusunun burun omuz hizasında merkezden iki yana doğru açılan iki spiral kabartı ile bezenmiş olmasıdır. Bu ayrıntı Isparta Müzesi örneğinde tespit edilmemiştir. Bununla birlikte, tanıttı̆̆ımız eserin yoğun biçimde kireç ile kaplanmış olmasından dolayı, belki de bu detay fark edilememiş olabilir. Yakın bir başka eser Tralleis Nekropolisi'nde saptanır ve 2. yüzyıla tarihlendirilir (Aydın, 2015, s. 33-37, 84, K18, lev. XXII). Genel form yapısı ve diskus süsleme şeması açılarından benzer olan bu örneğin, omuz üzerinde diskusu sınırlayan kabartı halka sayısı ve yüzük kulpu gibi detaylarla ayrıştı̆̆ı görülür. Tipolojik olarak tam uyumlu olmasa da diskusta yer verilen midye kabuğunun detayları açısından çok yakın olan bir örnek Bailey tarafindan Knidos buluntusu olarak değerlendirilir (Bailey, 1988, s. 333, 355-356, Q2898, fig. 111, pl. 92). Her iki kabukta, on bir dilimli bir dizayna ve kabuğun arka-orta kısmında yuvarlatılmış kabartıya sahiptir. Eser, 2. yüzyıla tarihlendirilir.

Sonuç olarak Isparta Müzesi envanterinde yer alan bu eserlerin yakın benzerlerinden hareketle 2. yüzyıla tarihlendikleri açıkça görülmüştür. Eserlerin üretim yeri meselesi tabii ki bir diğer çözümlenmesi gereken problemdir. Bu noktada da önemli verilere ulaşılmış olup, olası merkezlerden Ephesos, Pergamon ve Kibyra'nın özellikle öne çıktığı görülmüştür. Üretim yerleri sorusu ilk etapta ticari etkileşim sahası meselesini de akla getirir. Bu noktada eserlerin müzeye nereden gelmiş olduğuna da bakmak gerekir. İrdelediğimiz eserlerden 1 numaralı örnek Isparta Müzesi'nin kuruluş aşamasında İstanbul Müzesi'nden devir olarak envantere katılmıştır. Diğer örneklerin tamamı satın almadır. Bu eserlerden de sadece 7 numaralı örnek başka biri tarafından müzeye kazandırılmıştır. Kalan 6 kandilin tamamı aynı kişi tarafından getirilir. Müze yetkililerinden edinilen bilgilerde ise eserlerin daha çok Sütçüler, Eğirdir ve Atabey hattından gelebilecekleri sonucu çıkmaktadır. Tüm bu veriler doğrultusunda eserlerin bölge içinde bulunmuş oldukları düşünülebilir. Buna bağlı olarak da üretilmiş oldukları 2. yüzyıl içerisinde Pisidia Bölgesi'nin B. Anadolu ile etkileşim halinde olduğunu söylemek yanlış olmayacaktır. Bu çıkarım diğer kandil içerikli çalışmalarımızla da (Fırat - Metin, 2011; Fırat, 2014b; Firat, 2015a; Firat, 2015b) desteklenmektedir.

\footnotetext{
${ }^{10}$ Farklı kent ve koleksiyonlarda gözlenen, genel olarak 1. - 3. yüzyıllar aralı̆̆ına tarihlenen, benzer bezeme şemalı örnekler için bkz., Loeschcke, 1919, s. 37-40, 217-218, no. 550-551, 554, 556, 559, 568, taf. XIV, XVI; Dietrich - Dietrich, 1966, s. 11-12, no. 36; Radt, 1986, s. 49, 53, no. 559, abb. 25; Bailey, 1988, s. 85-87, 268-270, 356, Q1158, Q2898, Q2902-2903, pl. 50, 92; Rickman Fitch - Wynick Goldman, 1994, s. 192-193, Fig. 107; Germán Rodriguez, 1994-95, s. 270, 272, 278, 282-283, no. 5-6, lam. 58; Eckardt, 2002, s. 88-91, no. L1819, fig. 6; Bussière - Lindros Wohl, 2017, s. 87-88, 160, no. 114, 117, 237.
} 


\section{Katalog}

\section{Katalog Numarası : 1 (Levha 1.1)}

Müze Env. No: 13.161 .75

Buluntu Yeri : İstanbul Müzesi’nden bağış.

Hamur Yapısı : Bol miktarda ince mikalı içerikli, gözenekli ve sert.

Hamur Rengi : 5 YR 8/4 Pembe

Astar Rengi $\quad: 2.5$ YR 4/8 Kırmız1

Ölçüleri $\quad$ : $\quad$ U: $8.6 \mathrm{~cm} . \quad$ Y: $2.9 \mathrm{~cm} . \quad$ TÇ: $4.0 \mathrm{~cm}$.

\section{Katalog Numarası : 2 (Levha 1.2)}

Müze Env. No: 3.2.10

Buluntu Yeri : Satın alma.

Hamur Yapısı : Bol miktarda ince mika ve az miktarda kireçli içerikli, gözenekli ve sert.

Hamur Rengi : 10 YR 7/2 (Çok Açık Kahverengi)

Astar Rengi $\quad: 2.5$ YR 4/6 (Kırmız)

Ölçüleri $\quad$ : $\quad$ U: $7.1 \mathrm{~cm} . \quad$ Y: $2.4 \mathrm{~cm} . \quad$ TÇ: $2.4 \mathrm{~cm}$.

\section{Katalog Numarası : 3 (Levha 1.3)}

Müze Env. No: 2.13.09

Buluntu Yeri : Satın alma.

Hamur Yapısı : Bol miktarda ince mika içerikli, gözenekli ve sert.

Hamur Rengi : 5 YR 6/6 (Kırmızımsı Sar1)

Astar Rengi : 5 YR 5/8 (Sarımsı Kırmızı)

Ölçüleri $\quad$ : $\quad$ U: $7.9 \mathrm{~cm} . \quad$ Y: $2.4 \mathrm{~cm} . \quad$ TÇ: $3.6 \mathrm{~cm}$.

\section{Katalog Numarası : 4 (Levha 2.4)}

Müze Env. No: 2.3.10

Buluntu Yeri : Satın alma.

Hamur Yapıs1 : Çok az ince mika katkı11, gözenekli ve orta sert.

Hamur Rengi : 2.5 YR 6/8 (Açık Kırmızı) 
Astar Rengi $\quad$ : 10 R 5/8 (Kırmızi)

Ölçüleri $\quad$ : $\quad$ U: $10.0 \mathrm{~cm} . \quad \mathrm{Y}: 3.2 \mathrm{~cm} . \quad$ TÇ: $2.4 \mathrm{~cm}$.

\section{Katalog Numarası : 5 (Levha 2.5)}

Müze Env. No: 2.11.09

Buluntu Yeri : Satın alma.

Hamur Yapısı : Çok az ince mika ve kireç katkılı, çok az gözenekli ve sert.

Hamur Rengi : : 7.5 YR 5/6 (Koyu Kahverengi)

Astar Rengi : 7.5 YR 4/6 (Koyu Kahverengi)

Ölçüleri $\quad$ : $\quad$ U: $8.5 \mathrm{~cm} . \quad \mathrm{Y}: 2.7 \mathrm{~cm}$. TÇ: $3.0 \mathrm{~cm}$.

\section{Katalog Numarası : 6 (Levha 3.6)}

Müze Env. No: 2.2.10

Buluntu Yeri : Satın alma.

Hamur Yapısı : Çok az ince mika katkılı, çok az gözenekli, rafine ve sert.

Hamur Rengi : 7.5 YR 5/4 (Kahverengi)

Astar Rengi : 10 R 5/8 (Kırmızı) (yer yer beyaz astar izleri)

Ölçüleri $\quad$ : $\quad$ U: $10.0 \mathrm{~cm} . \quad \mathrm{Y}: 3.0 \mathrm{~cm}$. TÇ: $3.6 \mathrm{~cm}$.

\section{Katalog Numarası : 7 (Levha 3.7)}

Müze Env. No: 4.2.81

Buluntu Yeri : Satın alma.

Hamur Yapısı : Çok az mika, gözeneksiz, rafine ve yumuşak.

Hamur Rengi : 5 YR 6/6 (Kırmızımsı Sarı)

Astar Rengi $\quad: 2.5$ YR 5/6 (Kırmız1)

Ölçüleri $\quad$ : $\quad$ U: $8.3 \mathrm{~cm}$. Y: $2.5 \mathrm{~cm}$. TÇ: $3.2 \mathrm{~cm}$.

\section{Katalog Numarası : 8 (Levha 3.8)}

Müze Env. No: 11.9.88

Buluntu Yeri : Satın alma.

Hamur Yapısı : Çok az ince mika, gözeneksiz, yumuşak ve rafine. 
Hamur Rengi : 5 YR 6/8 (Kırmızımsı Sarı)

Astar Rengi $\quad$ : 2.5 YR 5/8 (Kırmızı)

Ölçüleri $\quad$ : $\quad$ U: $8.0 \mathrm{~cm} . \quad$ Y: $3.2 \mathrm{~cm} . \quad$ TÇ: $3.0 \mathrm{~cm}$.

\section{Katalog Numarası : 9 (Levha 3.9)}

Müze Env. No: 12.0.96

Buluntu Yeri : Satın alma.

Hamur Yapısı : Çok az ince mika ve kireç katkılı, gözeneksiz, yumuşak ve rafine.

Hamur Rengi : 2.5 Y 5/3 (Açık Zeytuni Kahverengi)

Astar Rengi $\quad$ : 2.5 Y 5/4 (Açık Zeytuni Kahverengi)

Ölçüleri $\quad: \quad$ U: $8.0 \mathrm{~cm} . \quad \mathrm{Y}: 3.6 \mathrm{~cm} . \quad$ TÇ: $3.0 \mathrm{~cm}$.

Katalog Numarası : 10

(Levha 3.10)

Müze Env. No: 2.12.09

Buluntu Yeri : Satın alma.

Hamur Yapıs1 : Çok az ince mika ve kireç katkıl1, gözeneksiz, yumuşak ve rafine.

Hamur Rengi : 5 YR 6/8 (Kırmızımsı Sarı)

Astar Rengi $\quad: 2.5$ YR 5/8 (Kırmızı)

Ölçüleri $\quad$ : $\quad$ U: $7.9 \mathrm{~cm} . \quad$ Y: $2.4 \mathrm{~cm} . \quad$ TÇ: $3.6 \mathrm{~cm}$. 


\section{Kaynakça}

Ayala, G. (1990). Alba-la-Romaine (Ardèche): les lampes en terre-cuite, Revue archéologique de Narbonnaise, 23, 153-212.

Aydın, O. (2015). Tralleis Batı Nekropolü Kandil Buluntuları. (Yayınlanmamış Yüksek Lisans Tezi). Aydın: Adnan Menderes Üniversitesi Sosyal Bilimler Enstitüsü.

Bailey, D. M. (1980). A Catalogue of the Lamps in the British Museum II. Roman Lamps Made in Italy. Londra: British Museum Publications Ltd.

Bailey, D. M. (1985). Excavations at Sidi Khrebish, Benghazi (Berenice), 3, 2. The lamps. Tripoli Department of Antiquities, in collaboration with the Society for Libyan Studies, London.

Bailey, D. M. (1988). A Catalogue of the Lamps in the British Museum III. Roman Provincial Lamps. London: British Museum Publications Ltd.

Brants, J. (1913). Antieke Terra Cotta Lampen Uit Het Rijksmuseum Van Oudheden te Leiden. Leiden.

Broneer, O. (1930). Corinth Vol. IV, Part 2: Terracotta Lamps. Cambridge: Harvard University Press.

Broneer, O. (1977). Isthmia III: Terracotta Lamps. Princeton, New Jersey.

Bussière, J. (2000). Lampes antiques d'Algérie, Montangac: M. Mergoil.

Bussiere, J., Lindros, W. B. (2017). Ancient Lamps in The J. Paul Getty Museum, Los Angeles: Getty Publications.

Civelek, A. (2001). Tralleis Nekropolisi Buluntuları Işı̆ğında Hellenistik ve Roma Dönemi Seramiği. (Yayınlanmamış Doktora Tezi). İzmir: Ege Üniversitesi Sosyal Bilimler Enstitüsü.

Deneauve, J. (1969). Lampes de Carthage. Paris: Centre National de la Recerche Scientifique.

Dietrich, B. C., Dietrich, A. C. (1966). The Rhodes University Vases. Acta Classica, 9, 1-13.

Eckardt, H. (2002). Lamp Production in West Stockwell Street, Colchester. Britannia, 33, 77-93.

Firat, M., Metin, H. (2011). Isparta Arkeoloji Müzesi Envanteri'nde Yer Alan Bir Grup Kandil. ADerg. (İsmail Fazlıŏlu Anısına), XVI, 143 - 154.

Fırat, M. (2014a). Aleksandreia Troas Antik Kenti 2013 Yılı Kazı Çalışmaları Sırasında Bulunan Kandiller. SDÜ Fen Edebiyat Fakültesi Sosyal Bilimler Enstitüsü Dergisi, 31, 209-234.

Fırat, M. (2014b). Isparta Müzesi Envanterine Kayıtlı Çark Yapımı: Roma Dönemi Öncesi. TTK Höyük, 7, 9-34.

Fırat, M. (2015a). Isparta Müzesi Volütlü Kandilleri. Uluslararası Sosyal Araştırmalar Dergisi, 8.36, $535-551$.

Firat, M. (2015b). Hellenistic Mouldmade Lamps at the Museum of Isparta. E. Lafl1 -S. Patac1 (Eds.). Recent Studies on the Archaeology of Anatolia, British Archaeological Reports, International Series 2750 (s. 217-283). Oxford: BAR.

Germán Rodriguez, F. (1994-95). Lucernas Romanas del siglo I d.C. procedentes de un vertedero de Mérida (Badajoz). Anas, 7-8, 269-283. 
Goerth Polaschek, K. (1985). Römische Lampen und Leuchter, Auswahlkatalog des Rheinischen Landesmuseums Trier. Mainz.

Gordon, J. M., Cova E. (2010). Romanesis in Cyprus: A Lamp from Athienou-Malloura. CCEC, 40, 2010, 277-294.

Granchelli, L., Groppelli, G., Rovida, A. (1997). Lucerne romane della collezione Pisani Dossi, Vercelli: Gruppo Archeologico Vercellese.

Hayes, J. W. (1980). Ancient Lamps in the Royal Ontario Museum I: Greek and Roman Clay Lamps. Toronto: Alger Press.

Güngör, E. (2011). Metropolis'de Bulunan Roma Dönemi Kandilleri. (Yayınlanmamış Doktora Tezi). İzmir: Dokuz Eylül Üniversitesi Sosyal Bilimler Enstitüsü.

Heimerl, A. (2001). Die römischen Lampen aus Pergamon: vom Beginn der Kaiserzeit bis zum Ende des 4. Jhs n. Chr. Berlin/New York: Walter de Gruyter.

Hellmann, M. C. (1987). Lampes antiques de la Bibliothéque Nationale II: Lampes pré-romaines et romaines. Paris: Bibliothéque Nationale.

Heres, G. (1967). Tonlampen als Zeugnise des frühkaiserzeitlichen Klassizismus. AntK, 10.2, 112-119, Taf. 34-35.

Heres, G. (1968). Die Werkstatt des Lampentöpfers Romanesis. Forschungen und Berichte, 10, 185211, taf. 28-33.

Iványi, D. (1935). Die pannonischen Lampen. Eine typologische-chronologische Übersicht, Budapeste. Ladstätter, S. (2013). Thymiaterien der Jüngeren Römischen Kaiserzeit aus Ephesos. G. Kökdemir (Ed.). Orhan Bingöl'e 67. Yaş Armağanı (s. 317-338), Ankara: Bilgin Kültür Sanat Yayınları.

Lerat, L. (1954). Catalogue des collections archeologiques de Besançon. 1, Les lampes antiques. Besançon: Observatoire national.

Loeschcke, S. (1919). Lampen aus Vindonissa. Ein Beitrag zur Geschichte von Vindonissa und des antiken Beleuchtungswesens. Zürich: Antiquarische Gesellschaft.

Menzel, H. (1954). Antike Lampen im römisch-germanischen Zentralmuseum zu Mainz, Mainz: Römisch-germanischen Zentralmuseum.

Metin, H. (2012). Kibyra Kandilleri. (Yayımlanmamış Doktora Tezi). Erzurum: Atatürk Üniversitesi Sosyal Bilimler Enstitüsü.

Oziol, T. Pouilloux, J. (1969). Salamine de Chypre I. Les lampes. Paris: E. de Boccard.

Oziol, T. (1977). Les lampes du Musée de Chypre, Salamine de Chypre VII. Paris: E. de Boccard.

Öztürk, N. (2003). Kyzikos Kandilleri. (Yayınlanmamış Doktora Tezi). Erzurum: Atatürk Üniversitesi Sosyal Bilimler Enstitüsü.

Pastutmaz, D. (2001). 1988-1998 Yılları Arasında Bulunan Knidos Kandilleri. (Yayınlanmamış Yüksek Lisans Tezi). Konya: Selçuk Üniversitesi Sosyal Bilimler Enstitüsü.

Perlzweig, J. (1961). Lamps of the Roman Period First to Seventh Century After Christ, The Athenian Agora Vol. VII. Princeton: J. J. A. Glückstadt. 
Ponsich, M. (1961). Les lampes romaines en terre cuite de la Maurétanie Tingitane, Rabat: Service des Antiquites du Maroc.

Radt, W. (1986), Lampen und Beleuchtung in der Antike. Antike Welt, 17.1, 40-59.

Rickman Fitch, C.,Wynick Goldman, N. (1994). Cosa: The Lamps, Michigan: The University of Michigan Press.

Rosenthal Heginbottom, R. (1981). Römische Bildlampen aus östlichen Werkstätten. Wiesbaden: Otto Harassowitz.

Shier, L. A. (1978). Terracotta Lamps from Karanis, Egypt, Excavations of the University of Michigan. Michigan: The University of Michigan Press.

Szentléleky, T. (1969). Ancient Lamps. Amsterdam: A. M. Hakkert.

Tekocak, M. (2013). Akşehir Müzesi’nde Bulunan Pişmiş Toprak Kandiller. (Ed.) M. Tekocak. K. Levent Zoroğlu'na Armağan (Studies in Honour of K. Levent Zoroğlu) (707-728). Antalya: AKMED

Temür, A. (2019). Giresun Müzesi’nde Bulunan Pişmiş Toprak Kandiller. Atatürk Üniversitesi Sosyal Bilimler Enstitüsü Dergisi, 23.1, 311-337.

Waagé, I. (1948). Antioch on the Orontes. Princeton: Princeton University Press.

Waldhauer, O. (1914). Kaiserliche Ermitage. Die Antiken Tonlampen. Petersburg.

Walters, H. B. (1914). Catalogue of the Greek and Roman Lamps in the British Museum. London.

Williams, H. (1981). Kenchreai: The Lamps: Eastern Port of Corinth. Brill Academic Publishers Zaccaria Ruggiu, A. (1980). Le lucerne fittili del Museo Civico di Treviso. Roma: G. Bretschneider. 
Levha 1

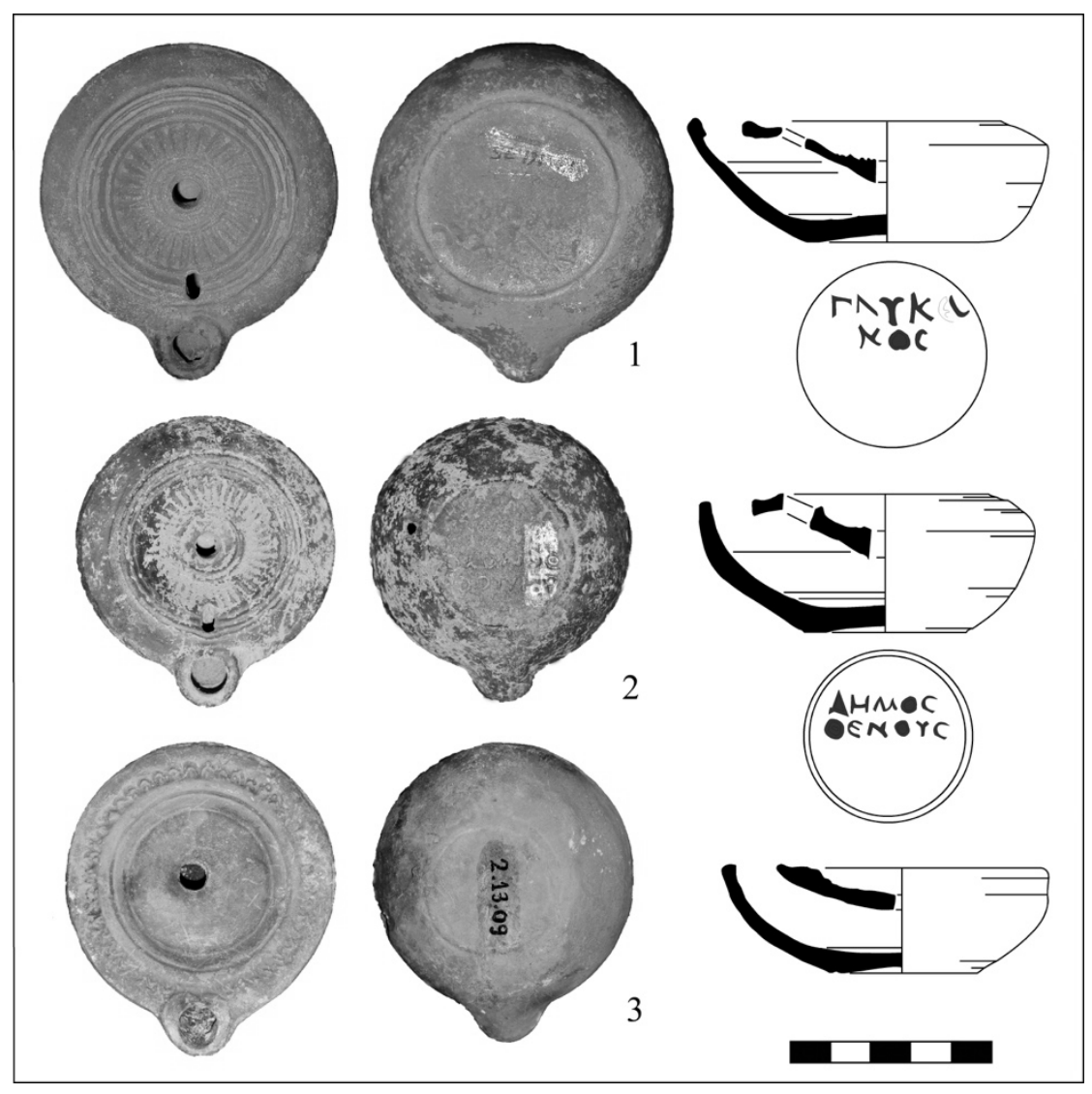

Levha 1

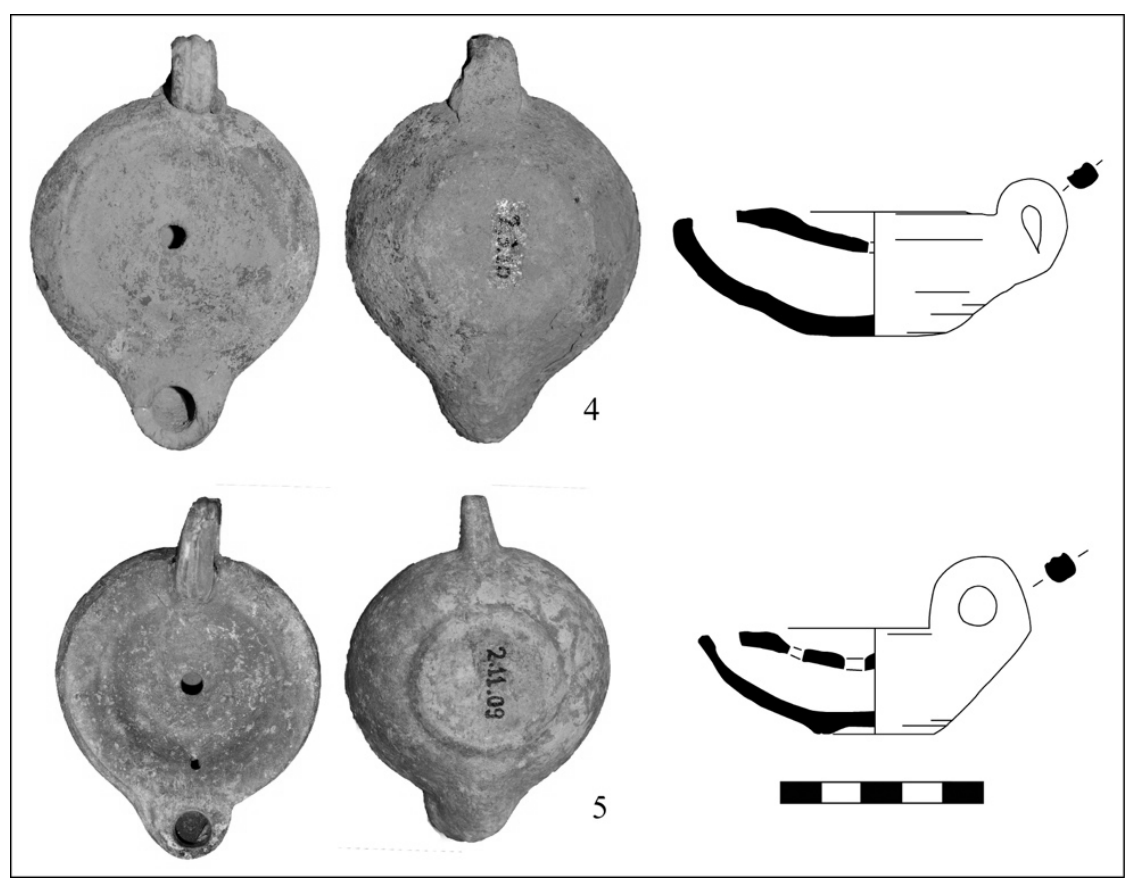

Levha 2 


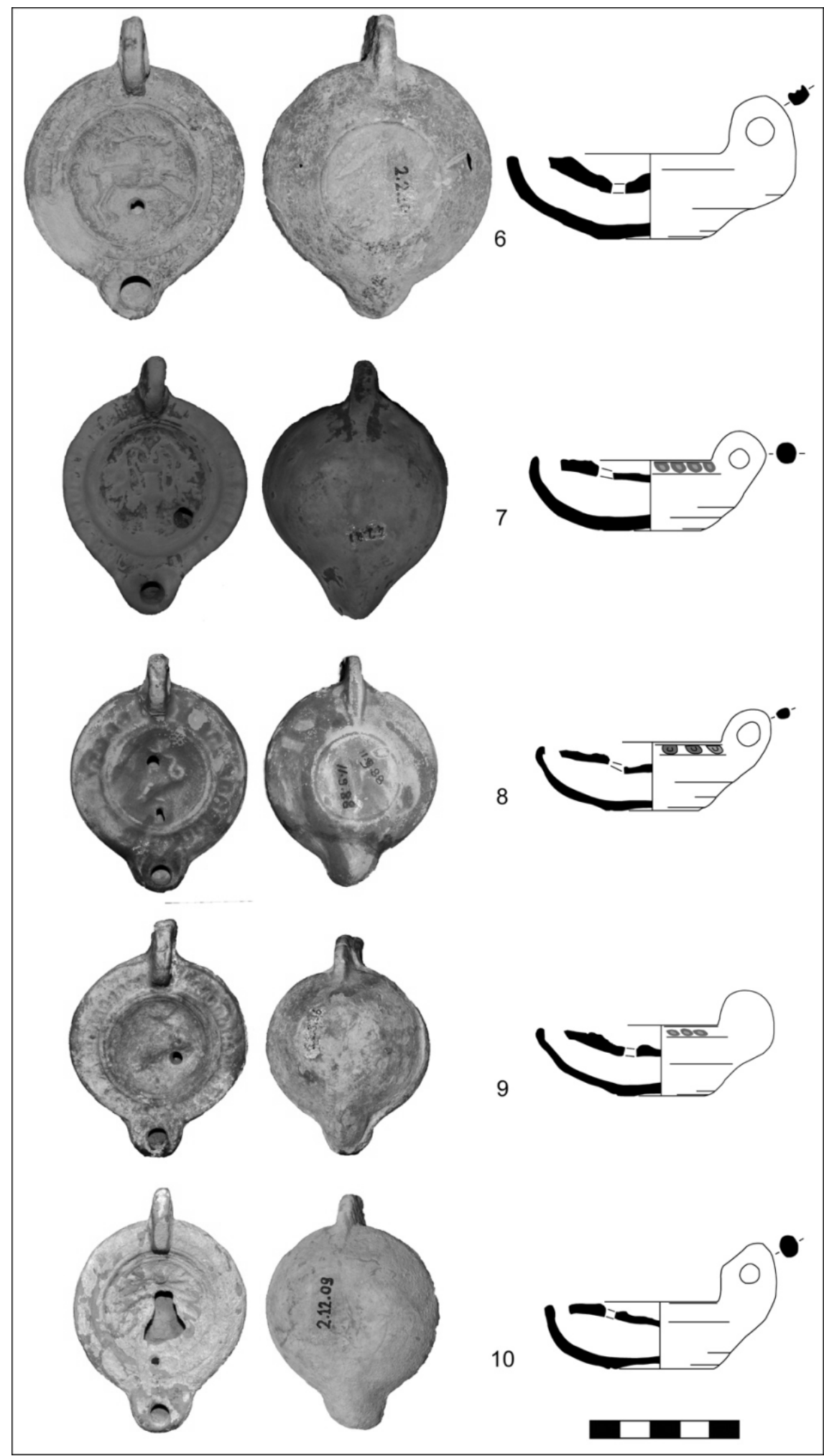

Levha 3 